\title{
Notes on Lessons from the Tin Agreement
}

\section{Carlos Fortin}

The International Tin Agreement is generally regarded as the one example of a working commodity agreement where producers and consumers successfully co-operate to stabilize prices and guarantee each other fair terms. This piece of received wisdom has of late been the subject of some doubt in the light of the difficulties experienced by the Agreement in facing the (admittedly rather extreme) situation of the world tin market in 1975, which is in fact endangering the very continuation of the scheme. The difficulties are a function of certain basic limitations of the Agreement as an instrument to deal with commodity market problems. The following notes will review some of those limitations and attempt to draw some tentative lessons for policy purposes.

Background: objectives, structure and mechanisms of the Tin Agreements

Attempts at introducing a measure of control in the world tin market date back to the $1920 \mathrm{~s}$, but it was only after the Second World War that the present system of International Tin Agreements was introduced. The basic reason for the emergence of the agreements was the great slump in the tin market that took place in the early 1950 s, due to overproduction in South East Asia and the end of the Korean War in 1953. There have been four agreements since July 1956, each lasting five years. The present one, the Fourth, came into force in July 1971, and lasts until June 1976. A Fifth Agreement has already been negotiated, but not yet signed. The objectives of the Fourth Agreement (which can be said to extend with minor differences to the other three) have been summarized by a former Secretary of the International Tin Council as follows:

"to ensure a degree of stabilisation-long term and short term-in the price; to obtain some long term adjustment between production and consumption; to increase the export earnings of the producing countries without detriment to the interests of the consuming countries; and to mitigate the difficulties for producers during surpluses of production and for consumers during shortages of production."1

The participants in the Agreements are both

1 Fox, W., Tin. The Working of a Commodity Agreement 1974. Mining Journal Books, London. p. 386. producer and consumer countries. Tin is produced almost exclusively in the developing world, and from the outset the Agreements included all major producers, representing about 90 per cent of world production. The main absentee is China, whose volume of production is not known, but which exported about 16,000 tons in 1975.2 (World production is about 200,000 tons a year.) The coverage of consumption is less complete: in the Fourth Agreement it includes 22 countries representing about 60 per cent of world consumption. The main absentee on the consumer side is the US, due to its unwillingness to lose, or at least share, control over its strategic tin stockpile. Producers and consumers make up the International Tin Council with equal voting rights based on their share of world production or consumption.

The main instruments of the Agreements are the operation of a buffer stock backed by the power to introduce export quotas and restrictions. The buffer stock has the purpose of allowing intervention (buying and selling) in the London Metal Exchange in order to support a floor and a ceiling price. The Council fixes the floor and ceiling prices and establishes a lower, a middle and an upper range. The buffer stock is operated by a Manager whose decisions are reviewed by the Council every three months, and who is empowered to buy or sell when the price moves to either the lower or the upper levels. When the price falls below the floor price or rises above the ceiling price, the Manager is under obligation to buy or sell. The stock is financed solely by the producers (with aid from IMF), is normally held partly in metal and partly in cash, and in the Fourth Agreement is the equivalent of 20,000 tons of tin valued at the July 1971 , floor price (i.e. $£ 27$ million). The introduction of export control is decided by the Tin Council. There have been four periods of export restrictions: December 1957-September 1960; September 1968-December 1969; January-September 1973 and April 1974, to date.

Evaluation of the working of the Tin Agreements The summary of the objectives of the Tin Agreements quoted above raises the question of the compatibility or conflict of interests between producers and consumers. It seems clear that there are important areas of common interest,

2 Metal Bulletin, p. 21, London, 19 December, 1975. 
such as avoiding violent fluctuations in prices or in the availability of metal through time. However, the central issue has to do with the relative share of surplus between producers and consumers and on this issue there is, obviously, no commonality of interests. This question has recently become more salient in the light of international discussion on the New Economic Order, but the issue has always been present in the operation of the International Tin Agreements. The way in which it has been dealt with is essentially by concentrating the working of the agreements on the area where there is no conflict, namely that of the smoothing out of short term fluctuations of the price around the trend spontaneously given by international supply and demand, without any attempt independently to affect the trend. On the whole, this objective can be said to have been achieved, although it is extremely difficult to specify with any certainty how much of the relative price stability of the post-War period is due to the operation of the Agreements. ${ }^{3}$ Stability of income is a desirable goal for producers: it is not however, by itself a sufficient goal, particularly since revenue from tin is much more crucial for their economies than the cost of tin imports is for the consuming countries. In practice, the consumers appear to have recognized this difference in that, when the trend itself is subject to persistent pressures, the Agreements' primary objective appears to be to defend the floor price and only secondarily to maintain the ceiling price. Thus, the agreements have been fairly successful in supporting the floor price in periods of slump, while in periods of persistent pressure upwards, the solution has been to raise the whole price range, as shown in the following table:

\section{International Tin Agreements}

\begin{tabular}{|c|c|c|c|}
\hline \multicolumn{4}{|c|}{ Floor price } \\
\hline July & 1956 & $£ 640$ & p. long ton \\
\hline March & 1957 & 730 & \\
\hline January & 1962 & 790 & \\
\hline November & 1963 & 850 & \\
\hline November & 1964 & 1000 & \\
\hline July & 1966 & 1100 & \\
\hline December & 1967 & 1283 & \\
\hline October & 1970 & 1350 & p. metric ton \\
\hline July & 1972 & M\$ 583 & $\begin{array}{l}\text { p. picul (equivalent to } \\
\text { previous price) }\end{array}$ \\
\hline September & 1973 & 635 & \\
\hline May & 1974 & 850 & \\
\hline February & 1975 & 900 & $\begin{array}{l}\text { (equivalent to about } \\
£ 3,030 \text { p. ton) }\end{array}$ \\
\hline
\end{tabular}

$3 \mathrm{~K}$. Barkman, "The International Tin Agreements", fourmal of World Trade Law, 9(5) pp. 455-524, September/October, 1975.
One should, however, keep in mind that the general trend of commodity prices through time is upwards, due to inflation, and that in any case it is easier to defend a floor price than a ceiling price (since after the exhaustion of the buffer stock there is no way to retain control over the market). Furthermore, and perhaps decisively, the success of the Agreements in defending the floor price is a function of the generally conservative attitude towards upwards readjustments imposed by the consumers. ${ }^{4}$ If one adds that the consumers have consistently refused to accept any obligation to contribute to the buffer stock (although France and the Netherlands made voluntary contributions in 1975), the picture of the distribution of gains between producers and consumers begins to appear different from what the preceding table might indicate at first. In fact, it could be argued that the effect of the operation of the Agreements may well have been a net loss of total revenue to the producers, although the distribution through time has probably been more stable, thus avoiding periods of excessive hardship. It can also be said that the Agreements have been less successful in avoiding periods of hardship for the consumers.

The tensions suggested above were particularly evident in 1975. After a period of high prices in the first three quarters of 1974 , the market saw a drastic slump in the last quarter of 1974 and the beginning of 1975 . At the same time, the cost of imports for the tin operations increased considerably due to the high energy intensity of some of the processes. The producers then attempted to get the Council to decide on a considerably higher level of support. 5 This in fact would have required not only the consumers' agreement to the higher price ranges but probably a substantial contribution from them to increase the size of the buffer stock. The consumers refused to go along and after a period of internal tension the Council compromised on a moderate increase of the range in February 19756, and in April decided to introduce an 18 per cent reduction in exports. These measures, however, failed to produce any substantial impact on the level of prices, and at the end of the year it was being argued that the producers were in fact losing export revenue because of reduced exports without any increase in prices. There were reports of producers in fact circumventing the export restrictions in an attempt to maintain export revenue. The fate of the Agreement itself was said to be doubtful.?

\footnotetext{
4 Ibid, p. 521

5 Metal Bulletin, p. 17, London 28 January, 1975.

6 Ibid, 4 February, 1975.

7 Ibid, p. 21, 5 December, 1975.
} 
What was, and still is, of course, in debate is whether producers which control 90 per cent of supplies of tin and which are almost entirely financing by themselves the operation of the Agreement would not be better off by deciding to act unilaterally and establishing a minimum price. This would appear particularly feasible considering that the producers' control over supplies is not challenged either by recycled tin (technologically not possible) or by available substitutes. In the event, such an alternative has been explicitly or implicitly rejected by the producers, who seemingly still prefer the relative stability of income provided by the operation of the Agreement to the potentially higher but riskier gains from unilateral action. The existence of the US strategic stockpile, representing about one year's world consumption, is no doubt an additional deterrent against acting unilaterally. The latest moves of the Council have been to start negotiating a $£ 20$ million stand-by credit to increase the buffer stock, and to reduce further the export quotas in the first quarter of 1976. Possibly due to an awareness of the attractiveness of unilateral action, there have been also some changes on the consumer side: West Germany has decided to join the Fifth Agreement and the UK has announced a voluntary contribution to the buffer stock. There is even talk that the United States is considering the possibility of joining the Agreement.

\section{Some tentative conclusions}

As suggested above, the Tin Agreements have been fairly successful in attaining the modest objective of smoothing out short term fluctuations in the price curve. It has also helped to guarantee a minimum revenue to the producers through its success in supporting the floor price, which, furthermore, has been readjusted upwards at various points in time. It can be argued, though, that stability has been achieved at the expense of the producers accepting the consumers' conservative approach towards defining the appropriate price ranges, and that alternatively a unilateral scheme could have achieved both a stable and an overall higher price for the producers. Dramatic increases in the cost of imports for the producers in 1975, coupled with the heightened sensitivity to the question of the international share of surpluses created by the OPEC experience, have increased awareness of the costs, in terms of total export revenue, that the producers may be paying in order to secure stability of revenue. So far, the producers still believe the cost is tolerable. However, the signs of strain are visible.

In summary, it seems that arrangements like the
Tin Agreement are useful instruments to attain the limited objective of reducing short term fluctuations in the price of commodities. This in itself may be of interest to producers, as it results in a steadier level of revenue. It is not, however, adequate to satisfy what seems to be the increasingly general aspiration of producer countries, namely to effect a real transfer of surpluses from the industrialized to the developing world. At that point, the conflict of interest with the consumer countries becomes apparent. Short of features that take account of this issue (such as indexation), the promise of the Tin Agreement as a model for other commodities seems to be a flimsy one. 